\title{
WAYS OF FORMING PRIMARY SCHOOL TEACHERS-TO-BE PROFESSIONAL COMPETENCE IN MODERN PR CHINA
}

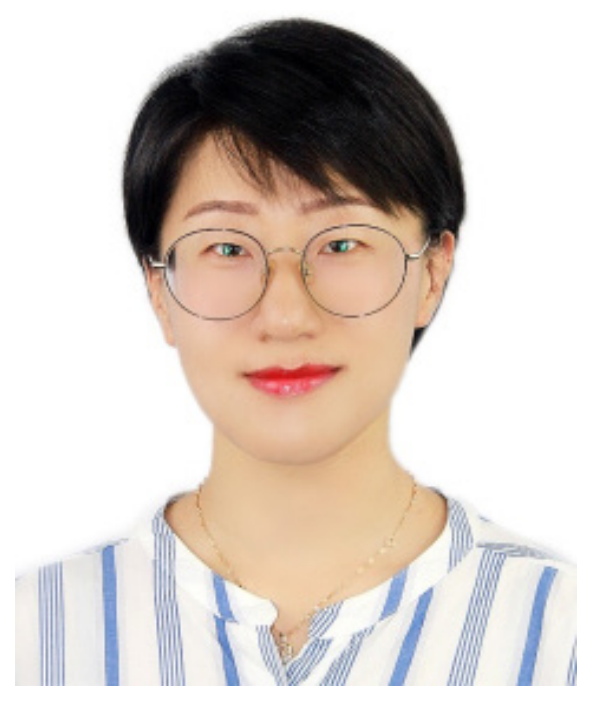

doi: 10.34142/astraea.2021.2.1.02

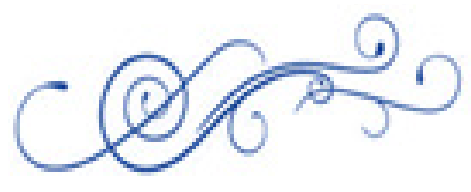

\section{PENG Chen}

Zhoukou Normal University, PR China ORCID: https://orcid.org.oooo-0002-3331-639X e-mail: sanduo@naver.com

\begin{abstract}
Modern reality and the demands of society put forward new requirements not only for the content of the future primary school teachers professional training (timely updates, variety of information, etc.), but also for the forms of the educational process organization. The variety and number of forms and methods that were used in the educational process during the training process of a future primary school teacher will definitely have a positive effect on the tools that the teacher himself/ herself will use in the practice activity. This article makes an attempt to present the forms of the primary school teachers-to-be educational processorganisation during the professional training course in educational institutions in PR China. Forms that are actively used and have a long historical and pedagogical tradition (mainly collective ones) as well as the ones that have not yet become widespread and are only being tested by the Chinese pedagogical practice are analyzed. The study is made as a part of «A Comparative Study on Professional Development of Primary School Teachers in China and South Korea» research program (registration number ZKNUC2017038)

Keywords: PR China; primary school teacher; teacher-to-be; professional competence; competence approach; professional education.

(C) Peng Chen, 2021
\end{abstract}




\section{АНОТАЦІЯ}

\section{Шляхи формування професійної компетності майбутніх вчителів молодшої школи в сучасній КНР}

Сучасна реальність та виклики суспільства висувають нові вимоги не лише до змісту професійної підготовки майбутніх учителів початкових класів (своєчасне оновлення, різноманітність інформації тощо), але й до форм організації навчального процесу. Різноманітність та кількість форм та методів, які використовувались у навчально-виховному процесі під час навчального процесу майбутнього вчителя початкових класів, безумовно позитивно впливатимуть на інструменти, які вчитель сам ви-користовуватиме у власній практичній діяльності. У цій статті зроблена спроба представити форми організації навчального процесу майбутніх вчителів початкової школи під час курсу професійного навчання у ВНЗ КНР. Аналізуються форми, які активно використовуються і мають давню історичну та педагогічну традиції (переважно колективні), а також ті, які ще не набули широкого поширення i лише перевіряються китайською педагогічною практикою.

Ключові слова: КНР; вчитель початкових класів; майбутній вчитель; професійна компетентність; компетентнісний підхід; професійна освіта.

\section{INTRODUCTION}

The peculiarities of the 21st century require from the modern system of a primary school teacher training to form a highly educated, socially active, creative, competitive personality who not only has a sufficient level and high quality of knowledge, but also uses it as a life tool; not only executes commands, but also generates new ideas, makes non-standard decisions, knows how to think critically, possesses communication skills, uses his/her potential for self-realization, has a responsible attitude to life, confidently responds to the challenge of the new millennium (Proposal..., 2018). Therefore, the modern education system, when training a teacher in general and a primary teacher in particular rather takes on the mission of creating a new educational environment for students to independently search for information and ways to apply it in practice, rather than simply transferring the amount of knowledge from a teacher to a student, equipping the latter one with certain algorithms and behavio-reaction 


\section{Peng Chen}

schemes, etc.

An important quality of a modern specialist is the use of integrated multi-subject competencies system. This can be ensured only in conditions when, in the learning process, those basic structural elements and relationships are purposefully formed to prepare specialists (and primary school teachers as well) for both the perception of new professional knowledge and the restructuring or revision of knowledge gained in the learning process earlier (Richaie, 2005).

\section{LITERATURE REVIEW}

Today in the world (and China is of no exception) there is a need to change the strategic and global goals of training a specialist in any profession, including primary school teachers. There is a shift in emphasis from the specialist's knowledge to his/ her human, personal qualities, which is considered both as the goal and the means of preparing him/her for future professional activities. The new educational paradigm as a priority of professional education in any field considers orientation to the individual's interests, formation of his/her erudition, development of independence in obtaining knowledge, that is also seen as a competence-based approach to education (Moore, 2003).

It can be noted that until now in the professional literature there is no single established definition of the concept of "competence", which is still at the stage of development and scientific comprehension. Also at this stage are the provisions on the definition of competence as an integral category, consisting of certain components. In other words, should professional competence be considered a set of certain competencies, which in their interaction form a professionally competent person, a professional, or is the professional competence of a representative of a certain profession a monolithic category? The competence-based approach to training a primary school teacher provides for both mastering basic competencies and purely professional ones.In the modern scientific space, competencies applicable to education are considered as follows:

- a dynamic combination of knowledge, understanding, skills, values, and other personal qualities that are formed as a result of training in the curriculum and are seen as the basis for a graduate's qualifications (Lahn, 2017);

- a certain amount of personal knowledge, which allows a person tojudge something, 
to express a convincing, authoritative opinion (Career readiness, 2019);

- a set of general and professional training, which allows a specialist to adequately respond to the needs of a particular workplace or work performed in the context of constant changes; depends on a person's attitude to his/her work, experience, diligence and ability to replenish the knowledge (Glover, 2014);

- a quality of a personality required for high-quality productive activity in the particular area (Doyle, 2017);

- the sphere of complex skills and personality traits; the ability to mobilize acquired knowledge and experience in a specific situation (Lee, 2017);

- a set of knowledge and skills necessary for a specialist to carry out effective professional activities: the ability to analyze and predict labor results, use up-todate information on a particular field of activity (Robinson, 1981).

The concept of "competence" is applied to various categories of specialists whose nature of work is associated with decision-making, with deep knowledge in a particular area, which include primary school teachers in full measure. The competence-based approach in the training of primary school teachers is entirely justified, since, unlike subject teachers who work with older children, they must have in their arsenal an expanded toolkit for the formation of a student's competencies, since it is them who lay the foundations for all subsequent professional activities of a particular student and, in a large number of cases, shape his/her personality.

\section{AIM OF THE ARTICLE}

The purpose of this article is to present modern methods and ways of forming the pedagogical competence of future primary school teachers by forming a set of professional competencies. The article examines both the forms of fu-ture primary school teachers` educational activities ' organisation, which are actively used in modern practice of higher pedagogical education in the PR China, as well as those that today are just beginning to be included in the ac-tive future primary school teachers ' professional training toolkit of this coun-try and, mainly, which are borrowed ones from the pedagogical practices of other countries. Standing on the position that "a teacher in his pedagogical practice will use only those methods and activities that he $\backslash$ she went through in the educational process », today all the forms and methods described in the article are not only part of lecture presentations in institutions of 


\section{Peng Chen}

Peng Chen

professional and higher pedagogical education in the PR China, but also the of future pri-mary school teachers professional training process in modern China.

\section{METHODOLOGY}

While making the research mainly theoretical research methods were used, that is typical for scientific studies of this kind. Among the methods of theoretical research, such ones as abstraction, analysis, synthesis, idealization, induction, mental modeling, ascent from abstract to concrete, etc. were used to create a comprehensive picture of which ways and methods are used to form professional competence of Chinese primary school teachers-to-be. In particular, such methods were used:

- general scientific: analysis, synthesis, comparison and generalization of philosophical, psychological, pedagogical, cultural knowledge to define the concept of professional competence of primary school teachers-to-be, identify the essence of leading concepts, systematize the views of scientists on the problem of methods used in training of such kind of specialists in the Chinese educational institutions, generalization of the experience of researching the problem;

- the interpretation and analytical method contributed to the study and analysis of scientific, educational and methodological literature, official regulatory documents in order to clarify the recommendations and nowadays approaches to analyse the ways and methods are used to form professional competence of primary school teachers-to-be as a pedagogical reality in the general system of providing educational services in the PR China;

- a prognostic method was used to determine the prospects for the development of the approaches mentioned in the article in the conditions of modern China,s.

As the research materials were used: Chinese and abroad scientific developments regarding the research problem; official documents and regulations (educational code of the PR China, laws, decrees, circulars, letters of the Ministry of Education of the PR China), statistical data of the National Institute of Statistics and Economic Research of the PRChina; Internet resources.

\section{RESULTS}

It is traditional for modern pedagogical science to distribute the competencies 
of a specialist (including a primary school teacher) into basic (leading, basic, key, universal) and professional (professionally oriented, special, professional and practical), although the boundaries between them are rather arbitrary. General competences are also usually referred to simply as "competence", and when it comes to competencies that are inherent or necessary only for representatives of a particular profession, the term "professional competence" is used. Basic (or key) competencies are those that are necessary for all citizens for personal fulfilment and development, active civic life, social cohesion and employment opportunities. In addition to purely subject specific knowledge and methods of action in highly specialised activities, any type of competence necessarily includes universal human qualities and abilities that do not depend on the scope of their manifestation. These are, for example, initiative, the ability to organise activities (own or of other people), the ability to adapt to new non-standard situations, the willingness to critically analyze and adequately assess the results of activities not only as significant for themselves, but as those that will have consequences for others. The above listed signs of general competence are based not just on knowledge and skills in one or another industry, but on the value priorities of the individual and the characteristics of his mental experience. Basic competence variables in different educational systems, their structure and list may change depending on the social and personal qualities of the future specialist and society as a whole.

\section{DISCUSSION}

Today, in the practice of primary school teachers training, the competencebased approach dominates (Ukraine, EU countries, Israel, USA, Canada, partly China). Competence-based approach is the orientation of the educational process upon achieving results, which are hierarchically subordinate basic, general subject and narrow subject competences (Proposal, 2018). The implementation of the competence-based approach in the educational process of primary school teachers presupposes to observe a number of didactic conditions. The first of them consists in a clear understanding of the didactic specificity by the participants of the educational process, embedded in the concept of "competence" as a pedagogical category, which can be characterized as a certain stage in the educational process, and its final result (Pillay \& etc., 2003). And it is the result that can be achieved by certain algorithms of 


\section{Peng Chen}

actions that can be perceived as ways of forming professional competencies, since a clearly defined result (which is embedded in the concept of a particular competence of a primary school teacher) presupposes a choice of methods for achieving it. Despite the variety of classifications of methods that are currently represented in the Chinese scientific and practical space, they are united by the fact that all methods include the cognitive activity of future specialists - primary school teachers. Therefore, practical teaching methods occupy one of the main places in the training of primary school teachers, taking into account the competence-based approach, since the source of knowledge is the activity of the future teachers themselves (Lee, 2017).

As for the basic competencies of a primary school teacher, in different sources their number reaches 54 , but the main ones include:

- Patience (good teachers are usually very patient; they focus mainly on finding a compromise between all participants in the educational process before continuing to look for ways to resolve conflict issues);

- Ability to analyze (effective teachers must have the skills of problem analysis in order to determine the interests of each of the parties to the educational process. A detailed analysis of the problem determines both the problem itself and the interest of each of the parties, and, therefore, its goals and the minimum results that the party can be satisfied with) ;

- Active listening (active listening involves the ability to read body language, as well as verbal communication. It is important to listen to the other side in order to find a place for a compromise and the most successful solution to the pedagogical situation);

- Emotional control (it is very important that the future teacher has the ability to control their emotions);

- Verbal communication (primary school teachers should be able to communicate clearly and effectively with all participants in the educational process, even when, due to age, the child cannot clearly express his state or desire in words);

- Skills of cooperation and teamwork (education and training is not an individual activity. An effective primary school teacher should have teamwork skills (both with a group of children, parents, colleagues) and foster an atmosphere of cooperation. Persons involved in the educational process should work together in order to reach a predetermined decision or as close as possible to it (this is especially true for the joint work of the primary school teacher and the parents / 
legal guardians of the child));

- Adaptability and mobility (teachers should be able to look for different ways to solve the problem. Instead of focusing solely on the ultimate goal of the educational process, the primary school teacher should also quickly adapt and focus on solving current problems that arise "here and now»);

- Directions for solving problems in a peaceful way (The task of a primary school teacher also lies in the plane of avoiding conflict both among students and between the subjects of the educational process. Setting up to resolve any conflict in a peaceful, legitimate, legal way should be not only a professional, but also a personal inner attitude elementary school teacher);

- The ability to make quick decisions (this competence comes to the fore in practical situations of interpersonal communication of children, parents, etc., as well as during the lesson);

- Interpersonal skills (primary school teachers must have interpersonal skills to maintain good working relationships with those involved in the educational process)

- Ethics and reliability (adherence to standards of business ethics and the situation of trust created by primary school teachers lead to the emergence of a favourable environment for learning and communication of students and other subjects of the educational process. All participants must trust the teacher and be sure that he will fulfil promises and agreements. The primary school teacher in this situation takes on the functions of the guarantor);

- Integrity (the teacher must provide complete and accurate information, maintain confidentiality and accountability for their own obligations, adhere to corporate and organisational policies and procedures);

- Resistance to stress (a teacher during work should be a model of emotional stability, be able to withstand pressure on an ongoing basis, work in difficult situations while maintaining productivity, quickly get out of a situation of emotional stress). (Finkel\& Hoffman, 2014; Lahn, 2016; Zilgour\& etc., 2015)

In the process of preparing a future primary school teacher, all methods of forming professional competencies can be conditionally divided into four groups:

- methods of organising and implementing initial-cognitive activity (lectures, conversations, clarification, disputations, example);

- methods of stimulating the educational activity of students-future primary school 
teachers (competitions, practical activities);

- methods of control and self-control (observation, questioning, socially useful workanalysis, self-observation, introspection, etc.);

- methods of forming common behaviour (pedagogical requirements, public opinion, management, training, assignment, creation of educational situations) (Livingstone, 2019)

It is generally accepted that any method of forming professional competencies, skills of a future primary school teacher, both by itself and in complex interaction with other methods, should serve the implementation of the following tasks:

- in the field of social relations: building two interactions; leaving a community that does not meet the goal of educational work; support for socially useful and professional ties at the macro and smaller levels;

- in the field of verbal communication: quickly distinguish between omissions, bluffs, the emotional state of students and other subjects of the educational process; hide your own emotions, mood goals, etc.;

- in the field of analytical activities: quickly and accurately analyze information about its objectivity, reliability, usefulness, timeliness, and the like;

- in the field of value orientation: to achieve a balance between the collective and the personal, impartiality, disinterest in the dominance of the interests of any of the subjects of the educational process;

- in the field of social responsibility, analysis of the consequences of the result of one's own professional activity, the ability to predict and accept the result of the educational process and its consequences;

- in the field of behavior: quick determination and adaptation of tactics for constructing the educational process in existing realities, actions in the conditions and within the legal field and norms of behavior, design of the functional space of the educational process in order to achieve the learning goal or as close as possible to it;

- in the field of self-determination and self-identification: self-recognition as a superstructure" that is impartial, uninterested in any aspect of the educational process, but only in the implementation of a predetermined goal of education as a process of communion, interaction, etc. sides (Richaie, 2005).

The changes taking place in the profession of a primary school teacher at the present time due to changes in the requirements of society have not yet been reflected 
in professional theory and practice and require additional attention, assistance in solving a number of contradictions on the way of forming a specialist-teacher of primary school in conditions changing stereotypes regarding traditional forms of his / her professionalization.

This section discusses both generally accepted methods that are used to form the professional competencies of future primary school teachers in educational institutions of a pedagogical profile of various levels of the PRC, and those that have not received widespread use for the day, but are recommended and justified in connection with the adaptation of foreign experience and modern realities of the country.

The method of explanation is mainly used during the teaching of new material, as well as in the process of consolidating knowledge and skills in seminars and practical classes. The success of using this method depends on its evidence, teaching logic, choice of arguments, the clarity of the teacher's speech, its pace, and her ability to speak (Lee, 2017). In the process of training primary school teachers, this method is used at the first stages of training to provide applicants with a body of knowledge in psychology, pedagogy, behavioristics, learning processes in general, etc., as well as in the analysis and analysis of specific practical situations in order to explain the general mechanisms of behavior. participants in the educational process in the "from private to general" format. (Livingstone, 2019).

Instruction is mainly used in preparation for specific practical tasks. This method is an algorithm of actions in a typical situation. The purpose of this method is to form certain professional competencies of a future primary school teacher associated with general ideas about the course of the educational process as a type of activity, the process of preparing for a lesson, methods of collecting and processing initial information, drawing up documentation for a lesson, etc. (Livingstone, 2019) Storytelling as a sequential disclosure of the meaning of educational material is widely used to create an atmosphere, immersion of the future primary school teacher "in the realities" of the profession. Mostly used are stories of a scientific, popular scientific and descriptive nature. Scientific and popular science stories are based on the analysis of factual material, therefore, their presentation is usually associated with theoretical material, abstract concepts, general cultural principles, appeals to the background knowledge of future primary school teachers. Storytelling is an important method of forming the professional competencies of future primary school teachers, since 


\section{Peng Chen}

the very process of their preparation involves the student's individual work with a mentor or work in small and ultra-small groups. This format of work requires the establishment of a relationship of trust between the student / group and the mentor, as well as a relationship of trust between group members (Lee, 2017).

Cognitive games method is used most often in the organization of typical tasks of professional disciplines in the preparation of a future primary school teacher. He fosters self-sufficiency in decision-making, forms the desire to acquire skills in the profession in a relatively short time. In the process of preparing future primary school teachers, this method can be used to stimulate students to independent and additional activities to develop theoretical material, to search for alternative methods of resolving situations, interesting cases that could be analyzed and used during classroom activities, and the like (Maier, 1991).

Creating problem situations method in the professional training of future primary school teachers is aimed at practicing specific skills of new knowledge that students must master. The use of this method creates a certain moral and psychological atmosphere in which the student receives moral satisfaction from intellectual growth. It is this method that forms in future primary school teachers a value attitude towards learning, towards their future profession(Lee, 2017).

Reliance on life experience method makes future primary school teachers more competent in choosing a strategy for working with children, finding a way out of a certain situation, analyzing the mistakes and advantages of a particular model of behavior of each of the subjects of the educational process, the manner in which they are presented with educational material, behavioral strategies, and the like. Even analyzing situations typical for the educational process, in which future primary school teachers acted as a party or only were present, can provide them with active material for processing, analysis, illustration of their own considerations and conclusions, etc. (Lee, 2017).

Specially organized professionally oriented training contributes to the transformation of the content of educational activities into an adequate content of the professional activity of the future primary school teacher and, accordingly, the formation of his professional identity. Such training can be considered as one of the varieties of cross-format training, that is, training devoid of the pressure of established norms, stereotypes, algorithms and formal principles. If specially organized training conditions are introduced, future specialists will be ableto practically apply educational 
information, integrate personal and professional growth, expand professional experience, and the like. This method uses semiotic, imitation and social teaching models. Semiotic models include problem situations, tasks, tasks that contribute to the assimilation of the objective knowledge presented in them by students. Within the framework of simulation training models, future specialists correlate theoretical information with a professionally approximate situation and use it in their own practical actions. Social models contain problem situations and tasks that imitate professional ones and are solved in the process of dialogical interaction. Thus, educational information acquires a personal and professional meaning for future primary school teachers; contributes to the personal and professional development of the future specialist; the development of a subjective position regarding social reality; awareness and realization of their own potential (Aronson \&Carlsmith, 1968). It should be noted that this type of training for future primary school teachers can be considered rather a unified method of organizing both the process of acquiring knowledge and skills as a type of activity and teaching certain subjects.

Role-playing games. The "role-playing" technique, which is widespread today, was first used as a method in psychotherapy in the 1930s. By the late 1940s, roleplaying had become an established part of the training system for professionals in business, administration, security forces, police, and the like. In the 1970s, it began to be widely used as part of behavioral therapy to train specialists who must have special skills and abilities, since its capabilities in the formation and training of social skills were described and brought to light (Kalashnyk\& etc., 2018). Today, the use of role-playing has spread to various forms of education from elementary school to the highest echelons of government and the training of business leaders. In our article, role play is considered as a method of purposeful formation of one or another professional competence of a future primary school teacher as part of a practical method for modeling the educational process in a "real time" format. The enormous effectiveness of role-playing games as a way of forming certain professional competencies stems from the fact that they put participants in hypothetical situations and force them to make decisions in new and different ways, to promote individual and collective learning, as close as possible to real-world situations. Role-playing games also enable future primary school teachers to "transform" into any of the participants in the educational process, which greatly facilitates the understanding of the strategy of behavior, internal motives, goals and objectives of each subject of 
the educational process. The games, which are a form of theatrical performance, are usually followed by further questioning and analysis, in which participants, with the help of a mentor, reflect on how the exercise is progressing, what they have learned, and how these achievements relate to or differ from real-life situations. Role play is essentially nothing more than a rehearsal. Musicians and footballers, actors and firefighters all need to practice their skills. This is due to the fact that complex effective operations cannot be negotiated and disassembled within the framework of a lecture, practical training, independent work, etc. a complex system and preparation for the unforeseen are all frequent goals of role play" (Maier, 1991). It is the role-playing game that gives future primary school teachers the opportunity to form "mechanical memory", which allows them to carry out their professional duties at a high level in any situation.

Training. Training is a special form of training in which a person maximally masters new knowledge, gains new skills, looks at his own values and priorities, corrects, improves and develops certain qualities and properties of his personality, chooses for himself such forms and methods of behavior that correspond to her situation and personality. Among other forms of education, it is training that makes it possible to assimilate the information received by 90\% (Colley \& etc., 2011). Trainings are the most common method of forming professional competencies, in particular, for future primary school teachers and, mainly, today in the PRC are used in the system of advanced training and non-formal education. The changes that occur with future specialists during the training are the result of movement from external to internal, from the proposed patterns of behavior and activity - to their awareness and input into the cognitive and regulatory structures of the psyche in the form of skills, habits, attitudes, competencies. All this presupposes the creation of a specific environment during training, which would take into account the requirements of the professional reality of a primary school teacher and create a load on those psychological properties and attitudes that are subject to change. At the same time, it is believed that mental neoplasms formed in training, and those that arise as a result of the interiorization of the external professional context, activate self-correction and self-development in the future and already established specialist (Doyle, 2017), which contributes to the qualitative formation of professional competencies of various levels and complexity. 


\section{CONCLUSIONS}

All researchers of the formation of professional competencies of future primary school teachers are unanimous that special attention in this process in modern conditions should be paid to interactive forms and methods of teaching (business and role-playing games, method of situations, discussion, self-presentation, etc.), requiring revealing the personal and emotional attitude of the future specialist to a certain situation, to the actions of others, requiring volitional efforts to solve the assigned tasks in the process of professional training. During seminars and practical classes, it is advisable to use such interactive teaching technologies, including various methods and techniques. Independent work should be aimed at mastering the mass of knowledge necessary for the formation and implementation of the professional competencies of the future primary school teacher. The use of the cluster approach method in the formation of professional competencies of primary school teachers, which is not used today in China, but is in the pedagogical arsenal of countries such as the USA, Holland, France, can be considered promising issues for further research in this area. If we paraphrase the classical definition of "cluster", then this term in the field of education can be understood as "a system of interrelated professional skills, knowledge, skills, achievements, the significance of which as a whole exceeds the sum of its components" (Lahn, 2016). As a conclusion, it should be noted that today the pedagogical practice of the PRC in the field of the formation of professional competencies of future primary school teachers uses a large instrumentarium of methods that relate to classical pedagogy and have proven themselves in the process of practical use, but actively adapts new experimental methods to their own needs and tasks in this area of training.

Funding: This study received no specific financial support.

Competing Interests: The author declares that there are no conflicts of interests regarding the publication of this paper

\section{REFERENCES}

Aronson, E. \&Carlsmith, J.M. (1968). Experimentation in social psychology. The handbook of social psychology. Vol.2(2). P.1-79.

Buchanan, D. \&Huczynski, A. (2013). Organizational Behaviour. Pearson Education, Limited. 837 p. 
Career readiness: professional competencies for college graduates' career success. (2019). Retrieved from:Official site of Virginia TECH https://career. vt.edu/experience/Internships/professional-competencies.html

Colley, H., Hodkins, P. \& Malcom, J. (2011). Informality and formality in learning. Lifelong Learning Institute University of Leeds. 756 p.

Cripe,E.\& Mansfield, R. (2002). The value-added employee: 31 skills to make yourself irresistible to any company. Gulf Professional Publishing. 194 p. Retrieved from:https://www.workforce.com/2002/09/03/31-core-competenciesexplained/

Doyle, A. (2017). A Step-by-Step Guide to a Successful Job Search. NY: BAL-ANCE.

Finkel, D. \& Hoffman, J. (2014). Seven Proven Principles to Grow Your Busi-ness and Get Your Life Back. Scale. 175.

Glover I. (2014). Role-play: An Approach to Teaching and Learning.

Retrieved from: https://blogs.shu.ac.uk/shutel/2014/07/04/role-play-an-approachto-teaching-and-learning/?doing_wp_cron=1522241599.2793579101562500 oooooo

Kalashnyk, N., Levchenko,Ya. \&Rakhlis, V. (2018). Practical issues of future negotiators ' trainings by the means of role-playing in non-formal educa-tion. Educational Studios: Theory and Practice: monograph / edit. S.T.Zolotukhina, I.M.Trubavina. Prague-Vienna: Premier Publishing. P.172-178.

Lahn, L.C. (2016). Competence and Learning in Late Career. European Edu-cational Research Journal. 2/1. Pp. 126-140.

Lee, Sh-L. (2017). Future work - Jobs and Universities in the 21 cent. GIS Retrieved from https://www.figur8.net/2017/06/17/future-work-universities-21stcentury/

Livingstone, D.W. (2019). Adults informal learning: definitions, findings, gaps and future research. Nall Working Paper 21. Pp. 15-237.

Maier, H. (1991). Role playing: Structures and educcational objectives. Jour-nal of Child and Youth Care. Vol. 6(4). P.145-150.

Moore, Ch. (2003). The Mediation Process: Practical Strategies for Resolv-ing Conflict. 3rd Edition Revised Edition, Jossey-Bass. 599.

Pillay, H., Boulton-Lewis. G., Wilss,L. \&Lankshear, C. (2003). Conceptions of Work and Learning at Work: impressions from older workers. Studies in Continuing Education. 25/1. Pp. 95-111.

Proposal for a council recommendation on Key Competences for LifeLong Learning. (2018). Brussels. Retrieved from https://eur-lex.europa.eu/legalcontent/EN/ TXT/PDF/?uri=CELEX:52018SCoo14\&from=EN

Richaie, K. (2005). Developmental Influences on Adult Intelligence. The Seat-tle Longitudinal Study. Oxford : University Press.

Robinson, P. W. (1981). Manipulating parents; tactics used by children of all ages and ways parents can turn the tables. Prentice-Hall.

Zilgour, P., Reynaud, D., Northcote, M. \& Shields, M. (2015). Role-Playing as a Tool to Facilitate Learning, Self Reflection and Social Awareness in Teacher Education. International Journal of Innovative Interdisciplinary Re-search. Vol. 2. p.8-20 


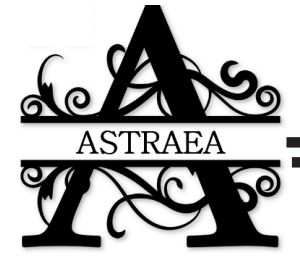

Received:19.02.2021

Accepted:29.04.2021

\section{Cite this article as:}

Peng, Chen.(2021)Ways of forming primary school teachers to be professional competence in modernPR China.Astraea, 2(1), 26-41. doi: 10.34142/astraea.2021.2.1.02

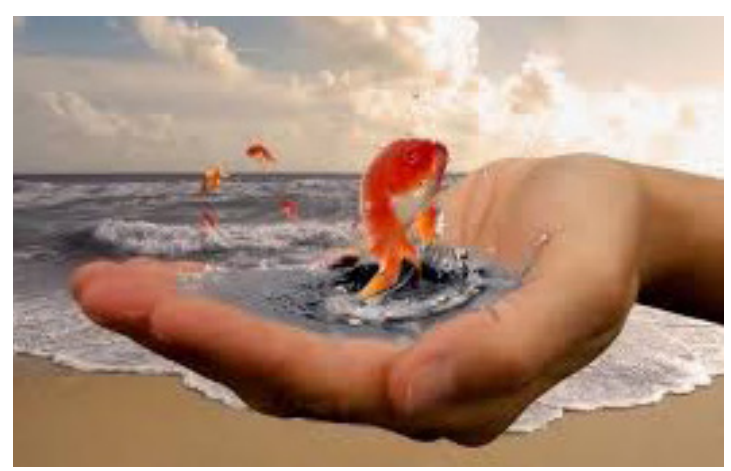

